\begin{tabular}{|lr|}
\hline $\begin{array}{l}\text { Social Work/Maatskaplike Werk Vol } 56 \text { No } 1 \text {; Issue } 6 \\
\text { http://socialwork.journals.ac.za/pub }\end{array}$ & doi:http://dx.doi.org/10.15270/56-1-791 \\
\hline
\end{tabular}

\title{
CONSEQUENCES EXPERIENCED BY WOMEN SURVIVORS OF HUMAN TRAFFICKING IN SOUTH AFRICA
}

Juliet Sambo, Gloudien Spies

Trafficking of women for domestic and sexual exploitation has devastating consequences for women survivors rescued in South Africa. Empirical findings revealed that women survivors of human trafficking (WSHT) suffer and endure intense and unspeakable traumatic physical, sexual, psychological, economic and social experiences. Trafficked women are denied fundamental human rights, including basic and broadly accepted individual freedoms. The article discusses a qualitative research study designed to explore the perceptions of women survivors concerning the consequences experienced by WSHT using one-on-one semi-structured interviews conducted in residential shelters for women in Gauteng province, South Africa. Recommendations are suggested regarding support for WSHT.

Dr Juliet Sambo, Lecturer, Department of Social Work \& Criminology, University of Pretoria, Pretoria, South Africa

Juliet.sambo@up.ac.za

Prof. Gloudien Spies, Associate Professor, Department of Social Work \& Criminology, University of Pretoria, Pretoria, South Africa

Keywords: women, women survivors, human trafficking and consequences, human trafficking,survivors, residential shelters 



\title{
CONSEQUENCES EXPERIENCED BY WOMEN SURVIVORS OF HUMAN TRAFFICKING IN SOUTH AFRICA
}

\author{
Juliet Sambo, Gloudien Spies
}

Juliet Sambo, ORiD Id: 0000-0001-7234-3238

Gloudien Spies, ORCiD Id: 0000-0001-6624-1702

Dr Juliet Sambo, Lecturer, Department of Social Work \& Criminology, University of Pretoria, Pretoria, South Africa

Prof. Gloudien Spies, Associate Professor, Department of Social Work \& Criminology,
University of Pretoria, Pretoria, South Africa

Keywords: women, women survivors, human trafficking and consequences, human trafficking,survivors, residential shelters

\section{INTRODUCTION AND PROBLEM STATEMENT}

Trafficking in women remains a serious challenge in South Africa, despite the government's numerous efforts to stop it. The International Organization for Migration (IOM) (2007:1) states that thousands of abducted women are currently trafficked into the country every year and others are trafficked within the country. Trafficking of women for domestic and sexual exploitation is a flourishing business in the Southern African Development Community (SADC) region (Kerry \& CdeBaca 2014:348). This business is thriving as a consequence of the harsh living conditions mostly characterised by poverty, unemployment and a lack of prospects or alternatives in the countries or areas of origin. Reda (2012:18) adds that trafficked women are forced to work for more than 18 hours a day, without rest or pay. Some of the women victims are often raped, beaten and threatened with death. In some cases, they are locked up in a residence to prevent them from escaping the ordeal. This makes it difficult for victims to seek any form of support and instead suffer gross human rights violations in complete isolation with devastating consequences. Trafficked women suffer intense trauma on a physical, sexual, psychological, economic and social level as a consequence of human trafficking (Dixon, 2008:81), which can develop into post-traumatic stress (Kerry \& CdeBaca, 2014:33; Reda, 2012:18).

However, research has confirmed that the challenge is that trafficked women know too little about their rights or about the appropriate measures to take in order to protect themselves (Reda, 2012:18; Pearson, 2003:9). Trafficking activities contravene fundamental human rights, denying trafficked women basic and broadly accepted individual freedoms (Dixon, 2008:81). The study was undertaken in Gauteng Province because it is considered as the economic hub of South Africa and the economic power house in Southern African region (United Nations Education, Scientific and Cultural Organization, 2007:10). Consequently the province attracts a lot of economic migrants, including human trafficking syndicates that are involved in exploitation of women victims. The study revealed that women survivors of human trafficking originate from different parts of South Africa as well as from other countries. It is against this background that the researcher embarked on the exploration of the perceptions of women survivors regarding the consequences that they experienced after exposure to human trafficking in South Africa.

\section{GOAL AND OBJECTIVES OF THE RESEARCH}

The goal of the research study was to empirically explore the consequences of human trafficking as experienced by women survivors in South Africa.

The objectives for the study were:

- To describe the consequences of human trafficking that may be experienced by women survivors;

- To explore the perceptions of WSHT regarding the consequences experienced as a result of human trafficking 


\section{RESEARCH METHODOLOGY}

Qualitative research was deemed as an appropriate research methodology. This approach was chosen to provide a framework for the study to arrive at a more complete and in-depth understanding and analysis of this complex social problem (Fouché \& Delport, 2011:66; Bless, Higson-Smith Y Kagee, 2006:44). Applied research was deemed appropriate to explore the consequences experienced by women survivors of human trafficking in South Africa. By using a qualitative research approach, the researcher attempted to gain first-hand knowledge and a holistic understanding of the field through a flexible strategy or problem formulation and data-collection method, which took shape as the investigation proceeded (Fouché \& Delport, 2011:65). In this qualitative study a collective case study research design was utilised during which the researcher used semi-structured interviews that were supported by an interview schedule to collect data from the participants. The population of the research study included WSHT residing at three shelters in Gauteng province, namely Mali Martin Polokegong Centre (MMPC), The Potter's House (TPH) and the Beth Shan Centre of the Salvation Army. The study focused on the exploration of the consequences experienced by 12 women survivors of human trafficking.

The most appropriate sampling technique for this qualitative study was the non-probability, purposive and snowball-sampling method, because cases were selected randomly based on the experiences or knowledge of the participants. Furthermore, selection of participants also relied solely on the researcher's judgment (Strydom \& Delport, 2011b:232-233)until saturation point was reached (Strydom \& Delport, 2011:392). The focus was to explore and understand the perceptions of survivors regarding their experiences after exposure to human trafficking.

The researcher drew upon the ecosystems theory (EST) in conjunction with the person-centred approach (PCA) as the theoretical framework for the study. Hence, the focus was on the interaction between a woman survivor and the broader environment as well as the self of the WSHT with regard to her experiences of the situation (Grobler, Schenck and Mbedzi, 2013:15, 23).

The researcher conducted semi-structured, one-on-one interviews with women survivors of human trafficking who are living in the three selected shelters on the basis of the following selection criteria:

- WSHT who have been in the selected facilities for not less than two weeks;

- WSHT who have been receiving therapy for at least two weeks;

- WSHT of any nationality living in one of the selected facilities. Interpreters were used for those who could not speak English;

- WSHT who were 18 years or older at the time of the study;

- WSHT who consented to participate voluntarily in the study.

The researcher also focused on issues of trustworthiness, confirmability, transferability and credibility, as discussed below.

Trustworthiness: Thomas and Magilvy (2011:151) indicate that data verification helps researchers to ensure the trustworthiness of the findings and establish trust or confidence in the finding of the study. Data were analysed by extracting themes or discovering patterns by looking at frequencies, magnitudes, structures, processes, causes and consequences in the chosen research area (Babbie, 2010:394). In order to ensure the trustworthiness of the proposed study, the researcher focused on awareness of personal bias (Creswell, 2013a:216). The semi-structured interview schedule was developed and tested during the pilot study before utilising it. Constructs were carefully conceptualised and were clear and unambiguous (Neuman, 2011:209).

Confirmability: Kumar (2011:185) refers to confirmability as the degree to which the findings could be confirmed by others. The researcher implemented member checking by soliciting information from participants about their perceptions of the consequences for women survivors of human trafficking. 
Peer review was crucial and the researcher participated in postgraduate supervision workshops and interacted with postgraduate colleagues who are familiar with the research topic in order to ensure confirmability. Most importantly, the researcher had frequent consultations with the supervisor for support and guidance (Schurink, Fouché \& De Vos, 2011:421).

Transferability: Transferability refers to the extent to which findings can be applied from a specific situation to another context or to other respondents (Schurink et al., 2011:420). The researcher provided comprehensive and thorough information regarding the description of the research context. This entailed that the observed transactions and processes, and the in-depth discussion of the findings and themes were used as mechanisms to ensure the transferability of data to another context.

Credibility: Credibility is an alternative to internal validity, in which the goal is to demonstrate that the study was conducted in a manner that ensures that the participants were accurately identified and described (Schurink et al., 2011:420). The researcher enhanced data credibility through repeated interviews until data saturation occurred (Creswell, 2014:189). Furthermore, the researcher read and reread the interview transcripts in order to capture accurate descriptions as well as the concerns of the participants.

\section{RESULTS AND DISCUSSION}

After transcribing and analysing data obtained from one-on-one interviews, the perceptions of the WSHT were explored. The key findings indicated that all the survivors experienced trauma and unbearable consequences as a result of the exposure to human trafficking.

Several themes relatred to the consequences for WSHT emerged when the data were analysed. The researcher used Creswell's qualitative data-analysis spiral process, which encompassed planning for the recording of data, data collection and preliminary analysis, managing or organising data, reading and writing memos, generating categories, themes and patterns, coding data, testing the emergent understandings, searching for alternative explanations and interpretations, as well as writing the report (Creswell, 2014:197-200; Schurink et al., 2011:403-418). In this study, data were described and classified, interpreted and categorised for identification of similarities. Subsequently, data were categorised according to different themes that emerged from one-on-one interview. The emerging themes were reviewed until no further information or themes could be identified or observed.

\section{TABLE 1}

THEMES AND SUB-THEMES FOR WOMEN SURVIVORS OF HUMAN TRAFFICKING AS PARTICIPANTS (WSHTP)

\begin{tabular}{|c|c|c|}
\hline Theme number & Themes & Sub-themes \\
\hline Theme 1: & $\begin{array}{l}\text { Understanding the percep- } \\
\text { tions of the women survivors } \\
\text { who were exposed to the } \\
\text { traumatic experiences of } \\
\text { human trafficking }\end{array}$ & $\begin{array}{l}\text { 1.1 A strong woman who never gave up, but endured the } \\
\text { terrible traumatic experience of human trafficking } \\
\text { 1.2 A woman who was cheated or deceived and trapped in a } \\
\text { human trafficking ordeal, but has now been rescued } \\
\text { 1.3 A woman who has accepted her painful past and is ready } \\
\text { to help others talk about their experience }\end{array}$ \\
\hline Theme 2: & $\begin{array}{l}\text { The challenges experienced } \\
\text { by women survivors of } \\
\text { human trafficking and how } \\
\text { it affects their lives }\end{array}$ & $\begin{array}{ll}\text { 2.1 } & \begin{array}{l}\text { Survivors trust in fellow humans is destroyed or } \\
\text { diminished }\end{array} \\
2.2 & \text { Endurance of painful experiences } \\
2.3 & \text { Low self-esteem and self-awareness of the women } \\
& \text { survivors of human trafficking } \\
2.4 & \text { Restricted movement and language barrier } \\
2.5 & \text { Forced to do stuff against their will } \\
2.6 & \text { Lack of knowledge and access to resources } \\
2.7 & \text { Feeling of hopelessness. }\end{array}$ \\
\hline
\end{tabular}




\section{Theme 1: Understanding the perceptions of the women survivors who were exposed to the traumatic experiences of human trafficking}

After data analysis, three sub-themes emerged, as discussed below.

\section{Sub-theme 1.1: A strong woman who never gave up, but endured the terrible traumatic experience of human trafficking}

A certain number of the participants expressed their perceptions about a woman survivor of human trafficking as a strong woman who never gave up despite enduring the terrible traumatic experience of the phenomenon. Their views were as follows: WSHTP 2 stated: "I consider a woman survivor of human trafficking as a strong woman who has endured difficulties. It is a lady who never gave up and survived in good times and in bad times." WSHTP 4 commented: "I am a survivor, who experienced a lot of bad things and I am alive because of God's intervention. I am proud of what I am now and I am out of danger." WSHTP 10 said: "I was a victim controlled and used by the cruel trafficker, but now I am safe and I see myself as a survivor and not a victim anymore."

The literature concurs with the empirical findings of this study and asserts that many victims choose to call themselves survivors to acknowledge that they survived a violent crime and are moving forward with their lives (Monarch Services, 2014:7). The women survivors are women who have endured and survived prostitution or other forms of sexual exploitation, forced labour or services, slavery, or practices similar to slavery (American Psychological Association, 2014:3). These are women who managed to leave and survive a trafficking situation and are ready to recover from the experience and continue with their lives (WHO, 2012:4).They consider the traumatic experience as a life lesson. They become confident in solving their problems and can plan for their future and become optimistic about a better future (Sari \& Khairunnisa, 2014:159).

\section{Sub-theme 1.2: A woman who was cheated or deceived and trapped in a human trafficking ordeal, but has now been rescued}

This sub-theme covers part of the definition of human trafficking by the Palermo Protocol, which states that force, fraud and coercion are key elements of the crime of human trafficking. Fraud refers to false or deceptive offers of employment, education, romance, marriage or a better life and/or debt release (Commission on Domestic \& Sexual Violence [CDSV], 2016:1; American Psychological Association, 2014:3). Participants shared their views as follows: WSHTP 7 explained: "I am a survivor, a poor woman who came to Gauteng under a pretext of a good job prospect, but ended up prostituting in a hotel. It pains me... (Sobs)." WSHTP 8 stated: "I was told that we were going for a church conference for 2 weeks. I was promised education in Ireland. However, I was rescued on the way to Dublin." WSHTP 9 stated: "I refer to myself as a woman survivor of human trafficking; a woman who was kidnapped, cheated, but now is free." WSHTP 11: "I was cheated that I was going to be made a queen, but I was forced to do bad things..." WSHTP 12 said: "I was rescued from a trap of sleeping with many men against my will for the benefit of a trafficker."

The concept is used by many in the social services field to recognise the strength it takes for the woman survivor who was deceived to continue on a journey towards healing in the aftermath of a traumatic experience of human trafficking. The concept is largely intended to honour those women who have suffered, or are suffering, the effects of being trafficked (Monarch Services, 2014:5; CDSV, 2016:5).

\section{Sub-theme 1.3: A woman who has accepted her painful past and is ready to help others talk about their experience}

In this sub-theme, some of the participants shared that a woman survivor is one who has accepted her painful past and is now ready to move on with her life. The participants further said that it is a woman who is ready to help others to share their stories. The following are statements made by the participants: WSHTP 1: "God gave me a second chance ... I understand the painful effects of being a victim of trafficking and I will help others." WSHTP 5: “Now I know what happened to me, though 
painful ... as a woman, I cannot be trafficked again and I cannot allow this to happen to a human being."

Lynch, Mason and Frost (2015:19) pointed out that women survivors of human trafficking are human beings whose worth and dignity were painfully violated. Therefore, with effective services and supportive assistance, they can thrive despite the painful experience and build fulfilling lives for themselves and their families.

\section{Theme 2: Impact of human trafficking on the WSHT}

The findings from the empirical study revealed numerous painful and agonising challenges experienced by WSHT. Consequently, a great number of participants shared their painful and emotional experiences while living in the trafficking environment. Deducing from the responses given during the one-on-one interviews, the following sub-themes unfolded and revealed how trafficking in women affected their lives.

\section{Sub-theme 2.1: Survivors' trust towards fellow humans is diminished}

Some of the participants expressed their views on how the trafficking experience destroyed their trust in other people. They indicated that it was difficult for them to trust anyone, including the social service providers, law enforcers or their families after their trafficking experience. The following views were shared by survivors: WSHTP 1: "I lost trust in my family and I think they would not trust me again. I also lost sense of humour and self-respect. In short, I lost trust in everyone." WSHTP 2: "(Pause) ... I have also lost trust in my family." WSHTP 4: "I lost trust of the people that loved me." WSHTP 5: "I need to overcome my bad experiences ... to regain trust and be trusted again. WSHTP 6: "I fear for my life, I don't trust anyone, not even the police, I don't sleep at night... (crying)." WSHTP 11: "I feel like I am being followed, spotted, my life is in danger, my trust was violated."

The literature confirms the above empirical findings which revealed that many women survivors harbour a significant distrust of law enforcement because of their previous negative experiences with law enforcement and the criminal justice system (CDSV, 2016:12). Furthermore, WSHT often do not immediately seek help or self-identify as victims of a crime. This is the result of several factors, including lack of trust, self-blame or specific rules made by the traffickers regarding how to behave when talking to law enforcement or social service providers (Monarch Services, 2014:7).

\section{Sub-theme 2.2: Endurance of painful experiences}

A great number of the women survivors also shared the painful experiences that they endured while in the trafficking situation and how it still affects them in their current life space. The following are the comments of the participants: WSHTP 4: "I felt pain ... I used to sleep with different men... it was painful ...(sobs)." WSHTP 5: "It made me feel unknown, that I have been used for things I never imagined. Unbelievable." WSHTP 7: "I was forced into prostitution with many men. I was secluded in a hotel in Hillbrow. I was later detained in Lindela for one month... (pause ... crying)." WSHTP 8: "Apart from the terrible occurrences which I endured due [to] trafficking, I could not see my family for a long time. I could also not study as I used to do." WSHTP 9 said in a low voice while looking down: "I miss home... I have lived a life full of misery." WSHTP 10: "I am aware that I was rescued from horror! However, I am concerned because I am very far from home. I cannot communicate well with service providers due to language problem. Food is new to me, it is different from my country, but it's ok. I have no money to go home. I was forced to use drugs, was raped many times... I have lost my own humanity." WSHTP 11: "I was beaten and left half dead; I was not allowed to go to the hospital. I was raped by many men, including body guards. I am living in fear, hiding. My business is suffering, my parents are receiving threats. I am living a nomadic life; running away from perpetrators. I had to move places from Cape Town to Gauteng, I am horrified. I feel that my life is still in danger, I am emotionally disturbed from rape, I cannot sleep at all. The other thing is that the shelter keeps my phone ... I can't communicate freely to my family." 
The literature concurs with these empirical findings from the research study that women survivors may be trafficked for a few days or weeks, or they may remain in a trafficking situation for years. Either way, WSHT face long-lasting consequences from their exploitation (CDSV, 2016:10). Furthermore, the women survivors who break free from their traffickers often find themselves in a situation of great insecurity and vulnerability. They may be physically injured, as well as physically and emotionally traumatised. They may be afraid of retaliation. They are also likely to have only few or no means of livelihood (United Nations, 2014:12). It is evident from the literature that WSHT are beaten into submission and are often denied any type of medical care (Calvo, 2014:16). Therefore, as a result of the traumatic experiences of human trafficking, women survivors display physical reactions such as headaches and stomach pain, sudden sweating and heart disturbance, changes in sleep and appetite, a weakened immune system, and alcohol or drug misuse (Banović \& Bjelajac, 2012:95). The woman survivor may experience feelings of isolation, guilt, shame, fear and denial. Hence talking with someone could make her feel less alone (Monarch Services, 2014:4).

\section{Sub-theme 2.3: Low self-esteem and self-awareness of the women survivors of human trafficking}

Some of the participants indicated that trafficking experiences affected their self-esteem. They lacked confidence, felt valueless and at times they could not understand themselves. They explained this as follows: WSHTP 2: "I didn't value myself. I didn't love myself and accept myself because of what I went through." WSHTP 3: "I was not safe and was low; my life was in darkness. Now that I am free, I want to go to school and work for myself." WSHTP 6: "I am not ready to disclose exactly what happened to me, but it was terrible stuff. I want to stay alone ... sometimes I wonder if I really know myself."

The literature also reflects the above findings, showing that women bound for forced prostitution often go through systematic rape and physical abuse that destroy their self-esteem and dignity (Human Trafficking, [s.a.]:2). Consequently, abusive coercion, low self-esteem and the need for familial connection are the most common reasons for involvement in prostitution (San Diego District Attorney, 2016:12). Furthermore, the women survivors of human trafficking exhibited higher anxiety levels, lower self-esteem as well as lower impulse control and uncontrollable displays of aggression (Calvo, 2014:13). Therefore, social workers should provide stable mentorship, encourage familial support and help the women survivors to build up their self-esteem, to value and protect their sacred bodies, and to educate them about the realities of trafficking in persons (San Diego District Attorney, 2016:12).

\section{Sub-theme 2.4: Restricted movement and language barrier}

Survivors may not know their physical location because they are restricted to one place and may not speak or understand the local language (Kaylor, 2015:4). Under regular surveillance, women did not have any opportunity to discuss personal matters or establish supportive relationships (Zimmerman \& Borland, 2009:19). Therefore, more information about human trafficking and available services should be printed in different languages and should be displayed at easily accessible places (FCJ Refugee Centre, 2016:10). The participants commented on this aspect as follows: WSHTP 6: "Language is a barrier that makes it hard for me to negotiate for my own rights and for other needs." WSHTP 7: "I can't speak local language fluently." WSHTP 10: "For me language is a problem to understand fully what is going on." WSHTP 12: "I am far from home and have no family support, no money and restricted movement and difficult to understand the language. In addition, the court process takes too long and I am not sure about the future."

\section{Sub-theme 2.5: Forced to do stuff against their will}

Women suffer gender-specific forms of harm and consequences of being trafficked such as rape, forced marriage, unwanted or forced pregnancy, forced termination of pregnancy and STDs, including HIV/AIDS (UN Commissioner for Human Rights, 2010:62). Victims are exploited by the service industries in restaurants, bars, strip clubs, nail salons and similar businesses (United Methodist Women, 2015:7). Many victims are forced to work in internet sites for adult services and the commercial sex 
industry relies heavily on human trafficking victims. Prostitutes, strippers, escorts, workers in massage parlours and brothels, and workers on phone chat lines are often victims. Right now, traffickers in many cities are exploiting workers and sexually abusing women and girls (United Methodist Women, 2015:7). WSHTP 8: "I was cheated, they took me from Rustenburg, forced me to use drugs and do prostitution when I was in Klerksdorp, with no money." WSHTP 9: He would expect me to smoke drugs and service the clients at any time; It was painful .... (pause) I had no choice.... (crying). Every time I feel low, the trafficker will give me more to smoke. When I am high, I could do anything; my brain is not thinking and not functioning well at that moment. I later became so weak and thin. Now I am better."

\section{Sub-theme 2.6: Lack of knowledge and access to resources}

The majority of the participants said that they lacked resources. Others mentioned that they needed money to send home to their children or parents. However, they did not even have money for food or other basic necessities such as medical treatment, much less for transport to go home. They commented as follows: WSHTP 10: "I have no finances to go home or send home, no job and I am in this shelter waiting for my embassy to help me go back home". WSHTP 8: "I have no money. Now I am sick, stomach cramps can be terrible, and they say it's withdrawals from drugs ... and I cannot get proper medical attention...(sobs)." WSHTP 9: "I cannot send money home and I am not free to go out or go shopping. The trafficker used to buy me clothes that were revealing the body, almost walking naked. Food was another challenge, as the trafficker would give me food when he felt like." WSHTP 12: "I am far from home and have no family support and no money. In addition, the court process takes too long."

Research findings revealed that the lack of knowledge about available services and how to access relevant services proves to be a challenge for the WSHT. The survivors sometimes also think that they do not deserve any services because of what has happened to them (FCJ Refugee Centre, 2016:10). The survivors often do not disclose their experiences and needs fully, even where screening systems have been implemented, for a number of reasons. These include trauma, language barriers, fear of authorities, or fear of retribution (CDSV, 2016:12). The WSHT often discover that their new-found freedom is accompanied by long-lasting mental, physical and financial challenges (Maney, Brown, Gregory, Mallick, Simoneschi, Wheby \& Wiktor, 2011:11). Furthermore, the women survivors may have difficulties in accessing legal services that they may require to address family law, immigration, public benefits and criminal defence (Solis, 2015:85).

\section{Sub-theme 2.7: Feeling of hopelessness}

The participants reported feelings of extreme sadness and hopelessness about the future. Research indicates that these survivors may be suicidal, have cognitive impairment and memory loss, and may become withdrawn. They may also have difficulty concentrating and display aggression and anger (Michigan Commission on Human Trafficking, 2013:16). Hopelessness is a condition in which the survivors suffer from a sense of powerlessness, arising from a traumatic event or persistent failure to succeed. It is thought to be one of the underlying causes of depression (Cherry, 2016:1). The participants shared on this as follows: WSHTP 11: "Though I am not sure who to trust, sometimes I feel as if $l$ am not understood by the service providers. It is like my life is stuck and I am not going anywhere, I wish I could disappear ... disappear than face all this". WSHTP 12: "I am far from home and have no family support and no money and I am not sure about the future." Participants perceive that human trafficking has enormous consequences in their lives.

\section{CONCLUSIONS}

The research study indicates that WSHT endure and survive multiple challenges that result from human trafficking. The findings reveal that WSHT experience unspeakable consequences that are traumatic in nature after being rescued from the ordeal of human trafficking and might require short- or long-term assistance. The consequences are numerous and affect the survivor in all aspects of her life. The consequences are physical, psychological, social, economic, spiritual, legal and educational in nature. 
All the participants were in agreement that lack of education and knowledge about issues of human trafficking and skills put them in a vulnerable situation. It was apparent from the participants that when women survivors are rescued, they are in a terrible state both physically and emotionally, that would require comprehensive intervention from a multidisciplinary team. Language was another aspect that the participants considered to be a barrier during intervention. However, the use of interpreters partly alleviated the problem. The problems identified by the participants included financial challenges and social relationships.

The findings also revealed that women continue to be vulnerable despite the current efforts of the government to curb human trafficking. The findings of the study indicated that the participants were not aware of their human rights, which also confirmed a general lack of knowledge about services that would be due to them, resulting in re-traumatisation, the delay of the healing progress or no progress at all. Furthermore, it was apparent during the research study that WSHT were not quite familiar with the Act on the Prevention and Combating of Trafficking in Persons (PACOTIP) Act 7 of 2013. The research findings were derived from participants residing in Gauteng province; however, attempts to ensure the trustworthiness of the study have increased the potential of the conclusions and recommendations to be applicable to WSHT in other provinces of South Africa.

\section{RECOMMENDATIONS}

Based on the research findings, the following recommendations are made and grouped according to practice, education, policy and future research.

Practice: It recommended that studies be conducted to explore the needs of WSHT with the aim of empowering them to step forward and speak up of their experiences and the need for healing. Recommendations for practice are noted based on the fact that WSHT need intensive therapy. It is further recommended that this field of practice in social work should be considered a specialised area with clearly defined social work tasks, roles and intervention strategies. Furthermore, recommendations are made stipulating that social workers in this field of service rendering should be encouraged to conduct community awareness programmes in order to prevent trafficking in women.

Education: Recommendations for training and education on the knowledge base and provision of an opportunity for the social workers and other role players in the field of service rendering to WSHT to be trained in the holistic interventions to render an effective service to the survivors of human trafficking.

Policy: Recommendations on the provision of adequate accessible resources to professionals in the field of service rendering to WSHT should be considered as paramount. Finally, it is recommended that the government should allocate more specific funds to support anti-trafficking activities, which include law enforcement, judicial training, victim assistance and protection.

Future research: Recommendations for future research include exploring the needs of WSHT experiencing the mentioned consequences and designing and developing of a holistic social work intervention programme for WSHT in South Africa to enhance the survivors' wellbeing.

\section{REFERENCES}

AMERICAN PSYCHOLOGICAL ASSOCIATION. 2014. Report of the task force on trafficking of women and girls. [Online] Available: https://www.apa.org/pi/women/programs/trafficking/report.pdf (Accessed 21/08/015).

BABBIE, E. 2010. The Practice of social research. (12 $\mathrm{ed})$. California: Cengage Learning.

BANOVIĆ, B. \& BJELAJAC, Z. 2012. Traumatic experiences, psychophysical consequences and needs of human trafficking victims. Vojnosanit Pregl, 69(1):94-97.

BLESS, C., HIGSON-SMITH, C. \& KAGEE, A. 2006. Fundamentals of social research methods: An African perspective. ( $4^{\text {th }}$ ed). Cape Town: Juta. 
CALVO, K. 2014. The psychological effects of human trafficking on the second generation. Tallahassee, FL: Florida State University College of Social Sciences and Public Policy.

CHERRY, K. 2016. What is learned helplessness and why does it happen? [Online] Available: https://www.verywell.com/what-is-learned-helplessness-2795326 [Accessed 18/12/2016].

COMMISSION ON DOMESTIC \& SEXUAL VIOLENCE. (CDSV). 2016. Post-conviction advocacy for survivors of human trafficking: A guide for attorneys. The Survivor Reentry Project. [Online] Available:

https://www.americanbar.org/content/dam/aba/administrative/domestic_violence1/SRP/practiceguide.pdf [Accessed 18/12/2016].

CRESWELL, J.W. 2014. Research Design: Qualitative, quantitative, and mixed methods approaches. $\left(4^{\text {th }}\right.$ ed). London: Sage Publications.

CRESWELL, J.W. 2013a. Qualitative inquiry and research design: Choosing among five approaches. $\left(3^{\text {nd }}\right.$ ed). University of Nebraska, Lincoln: Sage Publications.

DIXON, J. 2008. The impact of trafficking in persons. In: An introduction to human trafficking: vulnerability, impact, and action. [Online] Available: https://www.unodc.org/documents/humantrafficking/An_Introduction_to_Human_Trafficking___Background_Paper.pdf [Accessed 25/03/2019].

FCJ REFUGEE CENTRE. 2016. "From the ground up: Working with survivors for survivors" Human trafficking survivors led initiative. [Online] Available: http://www.fcjrefugeecentre.org/wpcontent/uploads/2016/02/Human-Trafficking-Survivors-Led-Iniciative.pdf [Accessed 01/04/2019].

FOUCHÉ C.B. \& DELPORT, C.S.L 2011. Introduction to the research process. In: DE VOS, A.S., STRYDOM, H., FOUCHÉ, C.B. \& DELPORT, C.S.L. (eds). Research at Grass Roots: For the Social Sciences and Human Service Professions. $\left(4^{\text {th }}\right.$ ed). Pretoria: Van Schaik.

INTERNATIONAL ORGANIZATION FOR MIGRATION. 2007. Eye on human trafficking: A bulletin of news, information and analysis on trafficking in persons in Southern Africa. Pretoria: International Organization for Migration.

KAYLOR, L. 2015. Psychological impact of human trafficking and sex slavery worldwide: Empowerment and intervention. [Online] Available: https://www.apa.org/international/pi/2015/09/leah-kaylor.pdf [Accessed 03/07/2017].

KERRY, J. F. \& CDEBACA, L. 2014. Trafficking in persons report. New York: Department of state publication.

KUMAR, R. 2011. Research methodology: A step-by-step guide for beginners. $\left(3^{\text {rd }}\right.$ ed). Los Angeles, CA: Sage Publications.

LYNCH, L.E., MASON, K.V. \& FROST, J.E. 2015. Faces of human trafficking - identifying, serving and supporting. A discussion guide. [Online] Available: https://ovc.ncjrs.gov/humantrafficking/Public_Awareness_Folder/DGV/Faces_of_Human_Trafficking Discussion_Guide-508.pdf [Accessed 04/07/2017].

MANEY, G.M., BROWN, T., GREGORY, T., MALLICK, R., SIMONESCHI, S., WHEBY, C. \& WIKTOR, N. 2011. Meeting the service needs of human trafficking Survivors in the New York City Metropolitan area: Assessment and recommendations. [Online] Available: https://lifewaynetwork.org/wp-content/uploads/2011/11/Hofstra-University-LifeWay-Network-Report2011.pdf [Accessed 04/07/2017].

MICHIGAN COMMISSION ON HUMAN TRAFFICKING. 2013. 2013 Report on human trafficking. [Online] https://www.michigan.gov/documents/ag/2013_Human_Trafficking_Commission_Report_439218_7.p df [Accessed 25/03/2019]. 
MONARCH SERVICES. 2014. Human trafficking: From victim to survivor. [Online] Available: http://www.monarchscc.org/wp-content/uploads/Human-Trafficking.pdf. [Accessed 25/03/2019].

NEUMAN, W.L. 2011. Social research methods: Qualitative and quantitative approaches. Upper Saddle River, NJ: Pearson.

PEARSON, E. 2003. Study on trafficking in women in East Africa. Available: http://arabwidows.org/upload/research/folder5/3.pdf [Accessed 25/03/2019]

PREVENTION AND COMBATING OF TRAFFICKING IN PERSONS ACT 7 of 2013. (Published in the Government Gazette, (36715) Pretoria: Government Printer).

REDA, A.H. 2012. An investigation into the experiences of female victims of trafficking in Ethiopia. Pretoria: UNISA. (DPhil Thesis)

SAN DIEGO DISTRICT ATTORNEY. 2016. ( $2^{\text {nd }}$ ed). Girls Only! [Online] Available:

https://www.sdcda.org/office/girlsonlytoolkit/girlsonlyflyerweb.pdf [Accessed 04/04/2019].

SARI, Y. \& KHAIRUNNISA. 2014. Resilience of young women as human trafficking victims international. Journal of Social Science and Humanity, 4(2):159-163.

SCHURINK, W., FOUCHÉ, C.B. \& DE VOS, A.S. 2011. Qualitative data analysis and interpretation. In: DE VOS, A.S., STRYDOM, H., FOUCHÉ, C.B. \& DELPORT, C.S.L. (eds). Research at Grass Roots: For the Social Sciences and Human Service Professions. $\left(4^{\text {th }} \mathrm{ed}\right)$. Pretoria: Van Schaik.

SOLIS, C. 2015. Addressing the needs of overlooked victims: Providing child support for children of human trafficking victims. Kalamazoo, MI: Western Michigan University.

STRYDOM, H. \& DELPORT C.S.L. 2011. Writing the research report. In: DE VOS, A.S. (ed.), STRYDOM, H., FOUCHÉ, C.B. \& DELPORT, C.S.L. Research at Grass roots for the social sciences and Human Service Professions. $\left(4^{\text {th }} \mathrm{ed}\right)$. Pretoria: Van Schaik.

THOMAS, E. \& MAGILVY, J.K. 2011. Qualitative rigour or research validity in qualitative research. Journal for Specialists in Pediatric Nursing, 16:151-155.

UN COMMISSIONER FOR HUMAN RIGHTS, 2010. Recommended principles and guidelines on human rights and human trafficking. Geneva: United Nations Publications.

UNITED NATIONS EDUCATION SCIENTIFIC \& CULTURAL ORGANIZATION. 2007. Human Trafficking in South Africa, root causes and recommendations. Paris: UNESCO.

UNITED METHODIST WOMEN. 2015. Human trafficking: Preventing, protecting, prosecuting. Available: https://www.unitedmethodistwomen.org/ht/packet.pdf [Accessed 08/04/2019].

UNITED NATIONS. 2014. Human rights and human trafficking fact sheet no. 36. Geneva: United Nations Publications.

ZIMMERMAN, C. \& BORLAND, R. 2009. Caring for trafficked persons: Guidance for health providers. Geneva: IOM. 